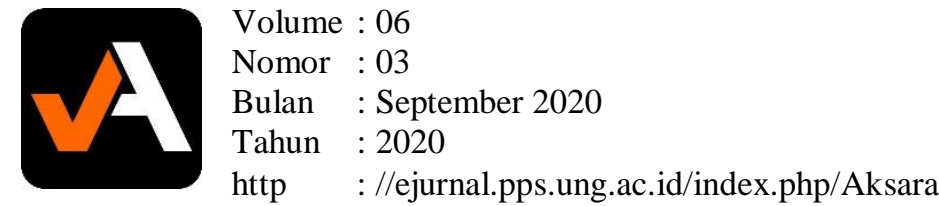

\title{
Existence Of Agreement In Foreign Language In The Process Of Verification In The Court
}

\author{
Yuhelson, Ramlani Lina Sinaulan, Bambang Utoyo \\ Universitas Jayabaya Jakarta Indonesia \\ yuhelson2870@gmail.com
}

Received: 18 Juli 2020; Revised: 21 Agustus 2020; Accepted: 28 Agustus 2020

DOI: http://dx.doi.org/10.37905/aksara.6.3.357-364.2020

\begin{abstract}
In line with the increasingly waning of the State borders in trade and business, then currently many trade and business agreements in Indonesia are made or entered into inforeign languages. The law has in principle governed the language of the agreement, in which the Law requires the use of the Indonesian language as the primary language of the agreement, while the secondary language may use language understood by those who do not understand the Indonesian language. The problems a rise when the parties to the agreement do not understand the language arrangements provided for by this law and use Foreign languages as the primary language even further as the only language used in an agreement. This is certainly contrary to the provisions of the law and vulnerable to create new legal problems.

The method used is jurical normative, amethod that examines the application of principles or norms in positive law, which examines the legal force of agreement made in private form in a foreign language. The data used are secondary data consisting of primary, secondary and tertiary legal materials. With regard to data analysis was done by using juridical qualitative analysis method. The legal theory used is the legal certainty theory according to Jan Michiel Otto and Substantiation Theory.

The results of this study is an agreement made or entered into ina foreign language has no legal substantiation before a Courtof law as they are contrary to the provisions of Article 31 of Law Number 24 of 2009. There fore the legal consequences of an agreement made in private form in a foreign language is considered to be null and void, and as a consequence, such agreement is considered never to exist.
\end{abstract}

Key words: the increasingly waning, the State borders in trade and business, many trade and business agreements

\section{PENDAHULUAN}

Hubungan hukum adalah hubungan antara dua subyek hukum atau lebih mengenai hak dan kewajiban di satu pihak berhadapan dengan hak dan kewajiban dipihak yang lain. Hubungan hukum seringkali dimuat didalam sebuah perjanjian, baik dibawah tangan maupun yang dibuat dihadapan pejabat umum yang lebih dikenal dengan nama akta otentik. Permasalahan kerap terjadi terkait dampak hukum dari bentuk perjanjian yang dipakai oleh para pihak untuk memaparkankan hubungan hukum diantara mereka, tidak jarang hal ini menimbulkan kerugian bagi para pihak.Perumusan hubungan hukum 


Volume : 06
Nomor $: 03$
Bulan $\quad:$ September 2020
Tahun $: 2020$
http $\quad: / /$ ejurnal.pps.ung.ac.id/index.php/Aksara

kedalam sebuah perjanjian diatur oleh peraturan perundang-undangan baik yang dibuat dibawah tangan maupun secara otentik, tidak sedikit perjanjian yang dibuat yang mengingkari peraturan-peraturan ini yang akhirnya secara hukum membatalkan perjanjian yang dimaksud yang berujung pada timbulnya kerugian bagi para pihak.

Hubungan hukum dalam masyarakat sering terjadi dalam suatu perjanjian. Suatu perjanjian adalah semata-mata untuk suatu persetujuan yang diakui oleh hukum. Persetujuan ini merupakan kepentingan yang pokok di dalam dunia usaha dan menjadi dasar bagi kebanyakan transaksi dagang seperti jual beli barang, tanah, pemberian kredit, asuransi, pengangkutan barang, pembentukan organisasi usaha dan termasuk juga menyangkut tenaga kerja. Perjanjian atau verbintenis mengandung pengertian suatu hubungan hukum kekayaan/harta benda antara dua atau lebih pihak yang memberi kekuatan hak pada satu pihak untuk memperoleh prestasi dan sekaligus mewajibkan pada pihak lain untuk memberi prestasi.

Dari pengertian singkat tersebut dijumpai beberapa unsur yang memberi wujud pengertian perjanjian, antara lain hubungan hukum yang menyangkut hukum kekayaan antara dua orang atau lebih yang memberi hak pada satu pihak dan kewajiban pada pihak lain tentang suatu prestasi. Perjanjian adalah hubungan hukum yang oleh hukum itu sendiri diatur dan disahkan cara penghubungannya, oleh karena itu perjanjian mengandung hubungan hukum antara perorangan/persoon adalah hubungan yang terletak dan berada dalam lingkungan hukum. Perjanjian atau perikatan diatur dalam buku ke III Kitab Undang-Undang Hukum Perdata.

Perkembangan kebutuhan manusia berjalan berdampingan dengan perkembangan ilmu pengetahuan dan teknologi, hal ini menyebabkan semakin meningkatnya kecendrungan bagi masyarakat dalam melakukan hubungan hukum terutama yang menyangkut bidang ekonomi dan sosial. Sehingga tidak mengherankan timbul perjanjianperjanjian dengan segala macam isinya, hal ini merupakan salah satu gejala sosial yang menarik akhir-akhir ini.

Dalam setiap perbuatan hukum perdata sangat diperlukan adanya kepastian hukum, ketertiban, dan perlindungan hukum, yang mana memerlukan adanya alat bukti yang dapat menentukan dengan jelas tentang hak dan kewajiban seseorang sebagai subjek hukum.Oleh karena itu hukum yang secara abstrak dikonkretkan melalui bahasa harus dapat dimengerti, dipahami dan dapat dijalankan oleh para pihak yang bersangkutan.

Akta dibawah tangan dibuat tidak dihadapan Notaris. Biasanya akta ini dibuat karena para pihak tidak mau repot dan sudah saling memiliki kepercayaan satu sama lain. Pada akta dibawah tangan Notaris tidak bertanggung jawab terhadap isi kesepakatan atau perjanjian. Kewenangan Notaris hanya bertugas melakukan legalisasi dan pencatatan dari akta dibawah tangan yang dibawa ke Notaris.

Notaris merupakan profesi hukum dan dengan demikian profesi Notaris adalah suatu profesi yang mulia (nobile officium). Dikarenakan profesi Notaris sangat erat hubungannya dengan kemanusiaan. Dalam ketentuan Pasal 1 angka 1 Undang-Undang Nomor 2 Tahun 2014 tentang Jabatan Notaris dinyatakan bahwa Notaris adalah pejabat umum yang berwenang membuat akta autentik dan kewenangan lainnya. Kewenangan lain dari Notaris yaitu, mengesahkan tanda tangan dan menetapkan kepastian tanggal surat dibawah tangan dengan mendaftar dalam buku khusus. Kewenangan ini merupakan legalisasi terhadap akta dibawah tangan yang dibuat sendiri oleh orang perseorangan atau oleh para pihak diatas kertas yang bermaterai cukup dengan jalan pendaftaran dalam buku 
khusus yang disediakan oleh Notaris (Pasal 15 ayat 2a UUJN). Dan membukukan suratsurat di bawah tangan dengan mendaftarkan dalam buku khusus atau waarmerking(Pasal 15 ayat $2 b$ UUJN).

Membahas masalah kekuatan alat bukti surat, karena apabila melihat ketentuan pada Pasal 1874, 1874a, 1880 dalam Buku IV KUH Perdata di mana dinyatakan bahwa surat-surat dimaksud perlu ada Legalisasi dan Waarmerking dari Notaris, walaupun kewenangan Notaris tidak hanya melegalisasi dan Waarmerking tetapi Notaris juga berwenang mengesahkan kecocokan fotokopi dengan surat aslinya dan juga membuat copy collation yaitu kopi dari asli surat-surat di bawah tangan berupa salinan yang memuat uraian sebagaimana ditulis dan digambarkan dalam surat yang bersangkutan.

\section{METODE PENELITIAN}

Metode Pendekatan yang digunakan dalam penelitian ini adalah pendekatan yuridis normatif, Pendekatan Yuridis yaitu dipergunakan untuk menganalisa berbagai peraturan perundang-undangan. Metode penelitian yuridis normatif atau metode penelitian hukum kepustakaan adalah metode atau cara yang dipergunakan dalam penelitian hukum yang dilakukan dengan cara meneliti bahan pustaka yang ada. Spesifikasi penelitian yang dipakai dalam penelitian ini adalah deskriptif analitis yaitu penelitian yang bertujuan untuk memberikan gambaran secara rinci, sistematis dan menyeluruh mengenai segala sesuatu yang berhubungan dengan masalah yang akan diteliti dan menggambarkan peraturan perundang-undangan yang berlaku berkaitan pembuatan Perjanjian yang menggunakan bahasa Asing dan dikaitkan pula dengan teori-teori hukum yang menyangkut permasalahan di atas.

Bahan hukum primer adalah bahan hukum yang mempunyai otoritas, yang terdiri dari peraturan perundang-undangan dan catatan-catatan resmi atau risalah dalam pembuatan suatu peraturan perundang-undangan serta putusan hakim. Bahan hukum primer yaitu bahan-bahan hukum yang sifatnya mengikat digunakan terutama berpusat pada perundang-undangan yang berlaku di Indonesia.

Teknik pengumpulan data yang dimaksudkan untuk memperoleh data dalam penelitian yang mendukung dan berkaitan dengan masalah yang akan dipaparkan dalam penelitian hukum. Setelah data bahan hukum primer, bahan hukum sekunder dan bahan hukum tertier yang berkaitan dengan penelitian ini dikumpulkan dan lengkap kemudian dianalisis, sehingga data tersebut dapat menjawab segala permasalahan yang mendasari di lakukannya penelitian ini. Pengolahan dan analisis data dalam suatu penelitian pada dasarnya tergantung pada jenis datanya. Dalam penelitian hukum normatif hanya mengenal data sekunder berupa bahan hukum primer, bahan hukum sekunder dan bahan hukum tertier, maka "dalam mengolah dan menganalisis bahan hukum tersebut tidak dapat melepaskan diri dari berbagai penafsiran yang dikenal dalam ilmu hukum".

Lokasi penelitian dalam penelitian ini dilakukan di Kota Administrasi Jakarta Timur dan Jakarta Barat. Dalam penelitian awal, penulis telah melakukan penelusuran guna mencari data pendukung. Dalam penelusuran itu penulis menemukan laporan penelitian dengan tema yang serupa walaupun dengan titik pokok permasalahan. 
Bulan : September 2020

Tahun : 2020

http : //ejurnal.pps.ung.ac.id/index.php/Aksara

\section{HASIL PENELITIAN DAN PEMBAHASAN}

A. Perjanjian Dalam Bahasa Asing Dalam Bentuk Akta Autentik Dan Surat Dibawah Tangan

Sebagaimana telah dijelaskan tersebut di atas tentang Akta Autentik, surat dibawah tangan dan perjanjian, maka dapat diketahui bahwa pengertian perjanjian berdasarkan uraian diatas merupakan kesepakatan yang dibuat oleh para pihak untuk mempunyai kekuatan hukum yang mengikat. Salah satu asas dalam perjanjian adalah asas kebebasan berkontrak, yang dapat dianalisis dari ketentuan Pasal 1338 ayat (1) KUH Perdata, yang berbunyi: "Semua perjanjian yang dibuat secara sah berlaku sebagai undang-undang bagi mereka yang membuatnya."

Berdasarkan Pasal 43 ayat (3) UUJN menyebutkan akta bisa dibuat dalam bahasa asing jika para pihak menghendaki. Artinya, kehendak para pihaklah yang menentukan. Kehendak para pihak adalah esensi dari sebuah kontrak/perjanjian. Namun Pasal 43 ayat (4) yang sama mewajibkan Notaris menerjemahkan akta ke dalam bahasa Indonesia jika akta itu sesuai kehendak para pihak dibuat dalam bahasa asing. Ketentuan Pasal 43 UUJN tersebut sesuai juga dengan ketentuan dalam UU No. 24 Tahun 2009, sehingga Akta Perjanjian dalam bahasa Asing yang dibuat oleh Notaris adalah sah mengikat para pihak.

Berbeda dengan perjanjian yang dibuat dibawah tangan, disini hanya tunduk pada UU No. 24 Tahun 2009, dimana perjanjian yang dibuat dibawah tangan wajib menggunakan Bahasa Indonesia, atau bila melibatkan pihak asing maka harus menggunakan 2 (dua) bahasa (Bahasa Indonesia dan Bahasa Asing). Dan perjanjian yang dibuat dalam bahasa Asing berarti melanggar aturan perundang-undangan. Begitu pula perjanjian yang dibuat dibawah tangan dalam bahasa Asing yang telah dilegalisasi atau didaftar/waarmerking oleh Notaris juga tidak memiliki kekuatan pembuktian, meskipun masih mengikat para pihak yang membuat perjanjian tersebut.

B. Kekuatan Pembuktian Perjanjian Dibawah Tangan Yang Dibuat Dalam Bahasa Asing Dalam Proses Pembuktian Di Pengadilan

Sebagaimana telah dijelaskan pada bab sebelumnya tentang perjanjian yang dibuat dibawah tangan bahwa perjanjian macam ini kekuatan mengikat dan pembuktiannya tidak sesempurna akta otentik, dengan demikian judex factie dapat saja menolak perjanjian dibawah tangan sebagai sebuah barang bukti atas terjadinya suatu tindakan hukum, dalam kasus yang menjadi dasar dibuatnya tesis ini dimana judex factie menganggap perjanjian yang dibuat dibawah tangan yang dibuat oleh para pihak sebagai dasar pelaksanaan prestasi mereka kepada satu dengan lainnya tidak sah dan tidak memiliki dasar hukum dengan demikian perjanjian tersebut dinyatakan batal demi hukum, hal ini didasarkan pada fakta bahwa perjanjian diantara para pihak dibuat dalam bentuk surat dibawah tangan selain itu surat tersebut juga dituliskan dalam bahasa asing (Inggris). Penulisan perjanjian dalam bentuk surat dibawah tangan saja sudah mengurangi nilai keabsahan dari sebuah perjanjian apalagi ditambah dengan penulisannya dilakukan dengan bahasa asing.

Jika kita mencoba untuk mengevaluasi dan mempelajari dasar/pola berpikir hukum dari judex factie maka terdapat beberapa pertentangan dengan teori-teori hukum umum yang berlaku antara lain adalah asas kebebasan berkontrak. Asas Kebebasan berkontrak didalam peraturan perundang-undangan di Indonesia terkait pembuatan perjanjian membuat para pihak bebas memasukkan klausul apapun yang ingin 


\begin{tabular}{|c|c|c|}
\hline & \multirow{2}{*}{\multicolumn{2}{|c|}{ Volume : 06}} \\
\hline & & \\
\hline & Nomor & $: 03$ \\
\hline & Bulan & : September 2020 \\
\hline & $\begin{array}{l}\text { Tahun } \\
\text { http }\end{array}$ & $\begin{array}{l}\text { : } 2020 \\
\text { : //ejurnal.pps.ung. }\end{array}$ \\
\hline
\end{tabular}

diperjanjikan oleh para pihak, termasuk akan tetapi tidak terbatas tentang pembuatan perjanjian dalam bahasa asing. Meskipun penggunaan bahasa sebenarnya sudah ada aturan tersendiri yang mengaturnya.

Penggunaan bahasa asing seringkali menimbulkan perbedaan penafsiran antara para pihak, hal ini berujung pada munculnya sengketa diantara para pihak, bahkan dalam beberapa kasus sampai diperkarakan di pengadilan, kendati demikian hal ini tidak membuat jera masyarakat umum dalam pembuatan perjanjian dibawah tangan dalam bentuk bahasa asing. Hal ini terbukti dengan masih banyaknya masyarakat yang membuat perjanjian diantara mereka dengan menggunakan bahasa asing sebagai bahasa pengantar didalam perjanjian yang mereka buat.

Perjanjian pada prinsipnya dibuat untuk mengetahui hak dan kewajiban masingmasing pihak. Dan apabila salah satu pihak melakukan wanprestasi, maka perjanjian tersebut bisa dijadikan sebagai alat bukti terkait tindakan hukum atau hubungan hukum yang terjadi diantara para pihak. Untuk dapat diterima sebagai sebuah alat bukti maka sebuah perjanjian tentunya harus memenuhi unsur-unsur yang diatur dalam undangundang.

Untuk meyakinkan Hakim tentang kebenaran dalil atau dalil-dalil yang dikemukakan dalam suatu persengketaan. Pembuktian merupakan bagian yang penting dalam hukum acara, karena dengan pembuktian dimaksudkan akan dapat dicapai suatu kebenaran yang sesungguhnya yaitu kebenaran dari hubungan hukum terhadap pihakpihak yang berperkara. Dengan jalan pembuktian maka akan dapat diketahui siapa sebenarnya yang salah dan siapa sebenarnya yang benar, sehingga dapat menjamin adanya perlindungan hak-hak asasi para pihak.

Dalam pembuktian yang harus dibuktikan adalah peristiwa bukan hukumnya. Peristiwa yang dikemukakan oleh Penggugat dan Tergugat belum tentu semuanya penting bagi Hakim guna dasar pertimbangan putusannya, tetapi peristiwa yang relevan itulah yang harus ditetapkan dan dibuktikan. Misalnya dalam perjanjian hutang piutang antara Penggugat dan Tergugat, maka yang harus dibuktikan adalah apakah benar-benar pada waktu dan tempat tertentu telah dipenuhi syarat-syarat sahnya suatu perjanjian, sehingga terjadilah perjanjian hutang piutang antara kedua belah pihak.

Dalam proses pembuktian yang wajib membuktikan atau mengajukan alat-alat bukti adalah yang berkepentingan dalam sengketa atau perkara, maksudnya adalah pihak Penggugat maupun Tergugat. Hal ini dapat dilihat dalam pasal 1865 Kitab UndangUndang Hukum Perdata yang menyebutkan "barang siapa yang mengaku mempunyai hak, atau menunjuk suatu peristiwa untuk meneguhkan haknya itu atau untuk membantah suatu hak orang lain, wajib membuktikan adanya hak itu atau kejadian yang dikemukakan itu".Jadi yang harus mengajukan alat bukti ialah para pihak dan yang menyatakan terbukti atau tidak adalah Hakim. Mengenai alat-alat pembuktian itu sendiri ketentuannya dapat ditemukan dalam pasal 1866 Kitab Undang-Undang Hukum Perdata yang menyatakan, maka yang disebut alat bukti itu, yaitu: Bukti surat; Bukti saksi; Persangkaan; Pengakuan, dan Sumpah.

Bukti Surat merupakan bukti dalam perkara perdata merupakan bukti yang utama, karena dalam lalu-lintas keperdataan sering kali orang dengan sengaja menyediakan suatu bukti yang dapat digunakan kalau timbul perselisihan dan bukti yang disediakan tadi lazimnya berupa tulisan. Bukti-bukti surat ini adalah golongan yang sangat berharga untuk pembuktian yaitu yang dinamakan akta. Suatu akta ialah suatu tulisan yang 


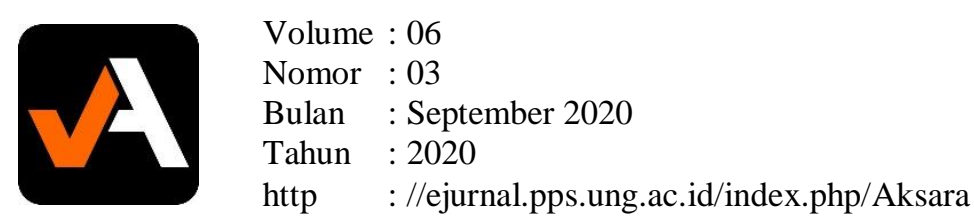

memang dengan sengaja dibuat untuk dijadikan bukti tentang suatu peristiwa dan ditandatangani. Dengan demikian maka unsur-unsur yang penting untuk suatu akta ialah kesengajaan untuk menciptakan suatu bukti tertulis dan penandatanganan tulisan itu.

Yang penting dari suatu akta memang penandatanganan itu, dengan menaruh tandatangannya seseorang dianggap menanggung tentang kebenaran apa yang tertulis dalam akta tersebut atau bertanggungjawab tentang apa yang ditulis dalam akta itu. Apabila tandatangan tersebut diingkari atau tidak diakui oleh ahli warisnya, maka menurut pasal 1877 Kitab Undang-Undang Hukum Perdata, Hakim harus memerintahkan agar kebenaran akta itu diperiksa dimuka Pengadilan.Sebaliknya apabila tandatangan dari akta diakui oleh orang terhadap siapa tulisan itu hendak digunakan, maka akta tersebut dapat mempunyai alat pembuktian yang lengkap terhadap pembuktiannya adalah bebas, dalam arti tergantung kepada penilaian Hakim. Dengan adanya pengakuan terhadap tandatangan berarti bahwa keterangan akta yang tercantum di atas tandatangan tersebut diakui pula. Hal ini dapat dimengerti, karena biasanya seorang yang menandatangani sesuatu itu untuk menjelaskan bahwa keterangan yang tercantum diatas tandatangan adalah benar keterangannya karena ada kemungkinan bahwa tandatangan dalam akta dibawah tangan tidak diakui atau diingkari.

Dengan demikian akta dibawah tangan hanya memberikan pembuktian material yang cukup terhadap orang untuk siapa pernyataan itu diberikan (kepada siapa si penandatangan akta hendak memberikan bukti).Sedangkan terhadap pihak lainnya kekuatan pembuktiannya adalah tergantung pada penilaian Hakim (bukti bebas). Akta dibawah tangan pada umumnya tidak mempunyai kekuatan pembuktian lahir, karena tanda tangan dari akta tersebut dapat saja dipungkiri.

Akta dibawah tangan merupakan akta yang dibuat oleh para pihak tanpa perantara seorang pejabat umum. Mengenai kekuatan mengikat para pihak akta di bawah tangan sama halnya dengan akta otentik, jadi apabila perjanjian dibuat secara sah yang artinya tidak bertentangan dengan undang-undang, maka berdasarkan pasal 1338 KUH Perdata, perjanjian tersebut berlaku sebagai undang-undang untuk mereka yang membuatnya, sehingga perjanjian itu tidak dapat ditarik kembali, kecuali berdasarkan persetujuan kedua belah pihak atau berdasarkan alasan-alasan yang ditetapkan undang-undang. Sedangkan untuk kekuatan pembuktian dari pada akta di bawah tangan, berdasarkan apa yang dinyatakan oleh Subekti bahwa suatu akta di bawah tangan ialah setiap akta yang dibuat tanpa perantara seorang pejabat umum, yang mana pembuktiannya dapat memiliki kekuatan pembuktian yang sama dengan suatu akta autentik (argumentum per analogian/analogi) apabila pihak yang menanda tangani surat perjanjian itu tidak menyangkal tanda tangannya, yang berarti ia tidak menyangkal kebenaran apa yang tertulis dalam surat perjanjian itu. Namun, apabila antara pihak-pihak yang melakukan perjanjian tersebut ada yang menyangkal tanda tangannya, maka pihak yang mengajukan surat perjanjian tersebut diwajibkan untuk membuktikan kebenaran penandatanganan atau isi akta tersebut.

Sedangkan pada akta autentik memiliki kekuatan pembuktian yang sempurna, karena akta tersebut dibuat oleh pejabat yang berwenang. Sempurna disini berarti ialah akta tersebut dengan sendirinya dapat membuktikan dirinya sebagai akta autentik, dapat membuktikan kebenaran dari apa yang disaksikan oleh pejabat umum, dan akta itu berlaku sebagai yang benar diantara para pihak dan para ahli waris serta para penerima 


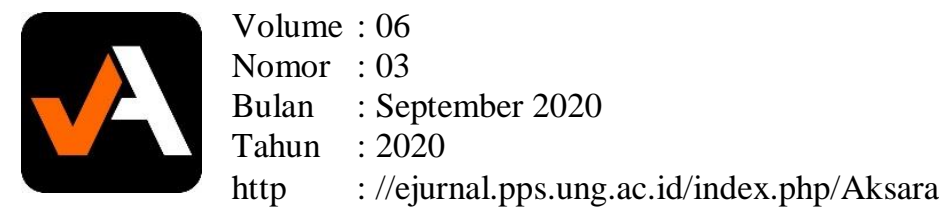

hak mereka. Akta autentik apabila dipergunakan dimuka pengadilan adalah sudah cukup bagi hakim tanpa harus meminta alat bukti lainnya.

Meskipun dalam pembuatan Perjanjian atau kontrak di Indonesia mengacu kepada asas kebebasan berkontrak, bukan berarti pembuatan perjanjian atau kontrak bisa dibuat bebas sesuai dengan keinginan dari para pihak. Hukum Perjanjian di Indonesia seperti yang dikatakan pada ruang lingkup diatas mengenai kebebasan dalam Perjanjian tetap ada mengatur batasan-batasan yang mana dapat dan tidak dapat diadakan dalam pembuatan kontrak tersebut di Indonesia. Seperti didalam KUH Perdata pasal 1320 KUH Perdata mengatur mengenai syarat-syarat sahnya perjanjian yakni syarat sah secara subjektif dan objektif. Dimana jika terjadi pelanggaran terhadap syarat subjektif dalam pasal 1320 yakni kesepakatan para pihak dalam perjanjian dan yang kedua kecakapan para pihak dalam perjanjian maka dapat dimintakan pembatalan, dapat dibatalkan artinya salah satu pihak dapat memintakan pembatalan itu. Perjanjiannya sendiri tetap mengikat kedua belah pihak selama tidak dibatalkan (oleh hakim) atas permintaan pihak yang berhak meminta pembatalan tadi (pihak yang tidak cakap atau pihak yang memberikan sepakatnya secara tidak bebas) sedangkan jika melanggar syarat objektif yakni sebab hal tertentu dan sebab yang halal maka perjanjian tersebut dapat batal demi hukum, batal demi hukum artinya adalah dari semula dianggap tidak pernah ada lahir suatu perjanjian dan tidak pernah ada suatu perikatan.

\section{PENUTUP}

Perjanjian yang dibuat di bawah tangan berbahasa Asing dalam proses pembuktian di Pengadilan, tidak memiliki kekuatan pembuktian, karena perjanjian tersebut dianggap tidak sah.

Hakim tidak boleh menilai alat bukti perjanjian yang dibuat dibawah tangan yang menggunakan bahasa asing sebagai bahasa pengantarnya, karena secara hukum tidak dapat diterima sebagai sebuah perjanjian yang sah dan mengikat kepada para pihak.

Agar perjanjian yang melibatkan pihak asing memiliki kekuatan pembuktian yang sempurna di Pengadilan, maka sebaiknya perjanjian dibuat secara akta autentik dihadapan Notaris yang berwenang. Dan apabila dalam akta tersebut menggunakan bahasa asing, maka Notaris harus menterjemahkan oleh pihak penerjemah yang telah disumpah. Dan perlu adanya sosialisasi menyeluruh kepada masyarakat tentang pentingnya melakukan perjanjian/kontrak apapun melalui pejabat Notaris, agar diperoleh akta yang memiliki kekuatan pembuktian absolut yang dapat melindungi kepentingan para pihak dari hal-hal yang dapat merugikan kepentingan para pihak.

\section{Daftar Pustaka}

Abdul Kadir Muhammad, Hukum Perjanjian, PT. Citra Aditya Abadi, Jakarta, 1992, hlm. 93

M. Yahya Harahap, Segi-segi Hukum Perjanjian, Alumni, Bandung, 1996, hlm. 6

Ira Koesoemawati dan Yunirman Rijan, Notaris, Raih Asa Sukses, Jakarta, 2009, hlm. 86 Abdul Ghofur Anshori, Lembaga Kenotariatan Indonesia , UII Press, Yogyakarta, 2009, hlm. 25

Pasal 1 angka 1 Undang-Undang Nomor 2 Tahun 2014 tentang Perubahan atas UndangUndang Nomor 30 Tahun 2004 tentang Jabatan Notaris (Lembaran Negara 


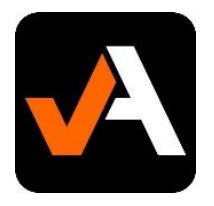

Volume : 06

Nomor : 03

Bulan : September 2020

Tahun : 2020

http : //ejurnal.pps.ung.ac.id/index.php/Aksara

Republik Indonesia Tahun 2014 Nomor 3, Tambahan Lembaran Negara Republik Indonesia Nomor 5491), selanjutnya disingkat UUJN

Ronny Hanitijo Soemintro, Metode Penelitian Hukum, Jakarta, Ghalia Indonesia, 1982, hlm. 9.

Soerjono Soekanto dan Sri Mamudji, Penelitian Hukum Normatif Suatu Tinjauan Singkat, Cetakan ke 11, PT. Raja Grafindo Persada, Jakarta, 2009, hlm. 1314

H. Zainuddin Ali, Metode Penelitian Hukum, Sinar Grafika, Jakarta, 2009, hlm.47

Amiruddin dan H. Zainal Asikin, Pengantar Metode Penelitian Hukum, Cetakan Keenam, PT Rajagrafindo Persada, Jakarta, 2012, hlm. 163.

R. Subekti, Pokok-Pokok Hukum Perdata, Intermasa, Jakarta, 1984, hlm. 139.

364 AKSARA: Jurnal IImu Pendidikan Nonformal 